Majalah Biomorfologi

Volume 30 Number 2, July 2020

p.ISSN:0215-8833, e.ISSN: 2716-0920, DOI:10.20473/mbiom.v30i2.2020.45-51

\title{
The profile of children with congenital rubella syndrome suffering from hearing disorders in Dr. Soetomo General Academic Hospital, Surabaya, Indonesia
}

\author{
Raudhatuzzahra Kesuma ${ }^{1}$, Haris Mayagung Ekorini ${ }^{2}{ }^{(1)}$, Tri Hartini Yuliawati ${ }^{3}$ \\ ${ }^{1}$ Medical Program, Faculty of Medicine, Universitas Airlangga, Surabaya, Indonesia, \\ ${ }^{2}$ Department of Otorhinolaryngology, Dr. Soetomo General Academic Hospital, Surabaya, Indonesia, \\ ${ }^{3}$ Department of Anatomy, Histology and Pharmacology, Faculty of Medicine, Universitas Airlangga, \\ Surabaya, Indonesia
}

\begin{tabular}{|c|c|}
\hline Article Info & ABSTRACT \\
\hline $\begin{array}{l}\text { Article history: } \\
\text { Received Dec 15, } 2019 \\
\text { Revised Apr 30, } 2020 \\
\text { Accepted May 10, } 2020 \\
\text { Published Jul 1, } 2020\end{array}$ & $\begin{array}{l}\text { Background: Congenital Rubella Syndrome (CRS) is an infection } \\
\text { that can cause hearing loss which is commonly found in infants in } \\
\text { Indonesia. The hearing screening of otoacoustic emission (OAE) and } \\
\text { automated auditory brainstem response (AABR) is essential as an } \\
\text { early screening to prevent speech and language development } \\
\text { disorders which may reduce the social function of the patient in the } \\
\text { future. Objective: To analyze the profile of children with CRS who }\end{array}$ \\
\hline $\begin{array}{l}\text { Keywords: } \\
\text { Hearing loss } \\
\text { Immunoglobulin } \\
\text { CRS }\end{array}$ & $\begin{array}{l}\text { suffer from hearing loss in Dr. Soetomo General Academic Hospital, } \\
\text { Surabaya, Indonesia in } 2015-2017 \text {. Materials and Methods: This } \\
\text { research employed a descriptive retrospective study by collecting } \\
118 \text { secondary data from the medical records. Results: CRS was } \\
\text { mostly found in } 0-3 \text { months age group ( } 76 \text { patients), and was } \\
\text { dominated by males ( } 62 \text { patients). The most common signs and } \\
\text { symptoms were congenital heart disease ( } 49 \text { patients), followed by } \\
\text { hearing loss ( } 37 \text { patients). The serological results were mostly } \\
\text { dominated by negative IgM and positive IgG ( } 40 \text { patients). The most } \\
\text { dominant results of hearing screening test were OAE and AABR } \\
\text { bilateral refer ( } 45 \text { patients). Conclusion: The profile of children with } \\
\text { CRS suffering from hearing loss is various, depending on which } \\
\text { country the research is conducted. }\end{array}$ \\
\hline
\end{tabular}

\begin{abstract} that can cause hearing loss which is commonly found in infants in Indonesia. The hearing screening of otoacoustic emission (OAE) and automated auditory brainstem response (AABR) is essential as an early screening to prevent speech and language development disorders which may reduce the social function of the patient in the future. Objective: To analyze the profile of children with CRS who suffer from hearing loss in Dr. Soetomo General Academic Hospital, Surabaya, Indonesia in 2015-2017. Materials and Methods: This research employed a descriptive retrospective study by collecting mostly found in 0-3 months age group (76 patients), and was dominated by males (62 patients). The most common signs and symptoms were congenital heart disease ( 49 patients), followed by ( The serological results were mostly dominant results of hearing screening test were OAE and AABR

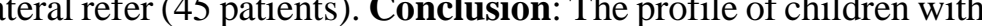
country the research is conducted.
\end{abstract}

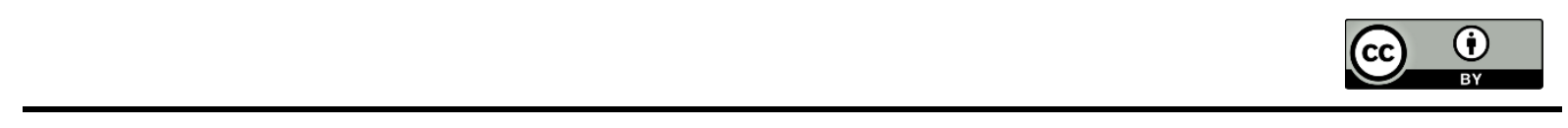

Corresponding Author:

Raudhatuzzahra Kesuma,

Faculty of Medicine, Universitas Airlangga,

Jl. Mayjen. Prof. Moestopo no. 47, Surabaya 60131, East Java, Indonesia,

zhrkesuma@yahoo.com

Haris Mayagung Ekorini

Department of Otorhinolaryngology, Dr. Soetomo General Academic Hospital

Jl. Mayjen. Prof. Moestopo no. 6-8, Surabaya 60286, East Java, Indonesia

hmekorini@fk.unair.ac.id

\section{BACKGROUND}

Hearing loss disorders are found in about 1-3 infants in every 1000 births. One of many indicators that becomes a risk factor for hearing loss based on recommendations from the Joint Committee on Infant Hearing $(\mathrm{JCIH})$ in 2000 is intra-uterine infections, such as toxoplasmosis, rubella, cytomegalo virus and herpes simplex (TORCHS) (Cherow, 2000). 1995-1996 in Tehran, Iran, there are 12\% of 113 
children aged 1-4 years who were suspected of having Congenital Rubella Syndrome (CRS), suffered from sensorineural deafness (Sadighi, et al., 2005). The CRS incidence rate in 1996 was quite high, with an estimated 22,000 children in Africa, 46,000 in Southeast Asia and 12,634 in the Western Pacific. While in Indonesia, data from 2012-2017 shows that 70\% of Rubella cases occur in children under the age of 15 (Ministry of Health, Republic of Indonesia, 2019). According to Hardiana, the Rubella virus in 2011-2013 spread in 50\% of regencies/cities in West Java, especially in the middle and east (Hardiana et al., 2015). Hearing loss due to CRS greatly affects the patients' life. The main impact of hearing loss is the inability of individuals to communicate with others. Besides, it can also inhibit the growth of children, due to the stunted language development. Thus, patients with hearing loss rarely get proper education because of the limitations they have (WHO, 2018).

Newborn Hearing Screening is a program to identify hearing loss in newborns. This screening is carried out for infants who have a risk of hearing loss (Targetted Newborn Hearing Screening) and all newborns (Universal Newborn Hearing Screening/UNHS). The screening method recommended by the Joint Committee on Infant Hearing 2000 (JCIH) in 2007 used automatic response detection. The gold standard for recommended hearing screening includes otoacoustic emission (OAE) and automated auditory brainstem response (AABR). The success of the screening program is largely determined by the availability of follow-up and early intervention facilities (Ekorini, 2016).

\section{OBJECTIVE}

To analyze the profile of children with Congenital Rubella Syndrome who suffer from hearing loss based on the distribution of signs and symptoms, the results of immunoglobulin $\mathrm{M}$ and immunoglobulin $\mathrm{G}$ tests, as well as the results of OAE and AABR hearing screening tests.

\section{MATERIALS AND METHODS}

The study was conducted at the Audiology Polyclinic of Dr. Soetomo General Academic Hospital, Surabaya, Indonesia in 2015-2017, starting from September 2018 to May 2019. The study applied a retrospective descriptive research design by collecting the patients' medical record data. The sampling was carried out by using the total sampling method which involved each subject that met the inclusion criteria, namely patients who have a complete, correct and clear medical record. The variables examined in this study were the basic data of the study including sex and age of the patients, distribution of the patients' signs and symptoms, the results of IgM and IgG laboratory tests, and the results of OAE and AABR hearing screening tests.

\section{RESULTS}

The results of the study showed that the number of the male patients was greater than the female patients, which were 62 patients in total 52.50 vs. 56 patients $(47.50 \%)$. The study also revealed that the number of patients was mostly dominated by the age group of $0-3$ months (76 patients; $64.40 \%$ ), followed by the age group of 4-6 months (26 patients; $22.00 \%$ ), the age group of 7-9 months (11 patients; 9.30\%), and the age group of more than 10 months (5 patients; $4.20 \%$ ) respectively.

The highest percentage of signs and symptoms were congenital heart disease as much as $38.30 \%$, followed by SNHL (Sensorineural Hearing Loss) as much as $28.90 \%$, congenital cataractsas much as $18.00 \%$, mental retardation as much as $9.40 \%$, and microcephaly as much as $5.50 \%$ respectively. There were 31 of the total 118 patients who did not do immunoglobulin testing due to the socio-economic conditions which made it impossible for them to carry out further tests. Besides, the patients also did not routinely do the scheduled controls. The total number of patients who had IgG and IgM test results consisted of 22 patients with positive IgM and positive IgG results, 1 patient with positive IgM and negative IgG results, 40 patients with positive $\operatorname{IgG}$ and negative IgM results, and 16 patients with negative IgG and negative IgM results. In addition, there were also 31 patients who came without IgG and IgM test results, and 8 patients who came without IgM test results, but had positive IgG results.

The results showed that there were 29 patients who obtained the OAE and AABR -pass\|t tests results, which means that the infants passed the hearing test screening. Besides, there were 11 patients who obtained the OAE -pass\| test results with a total unilateral AABR -refer\| $(\mathrm{P} / \mathrm{R}, \mathrm{R} / \mathrm{P})$ and bilateral (R/R), and 14 patients who obtained the OAE -referl, but obtained the AABR-pass $\|$ test results. 
In addition, there were 45 patients who obtained OAE -refer\| and a bilateral AABR -refer\| (R/R) test results. This also means that the infants did not pass the screening test and must be monitored at every stage of their development.

Table 1. Characteristics of CRS patients in the Audiology Polyclinic of Dr. Soetomo General Academic Hospital, Surabaya, Indonesia in 2015-2017

\begin{tabular}{lll}
\hline \multicolumn{1}{c}{ Characteristics } & $\begin{array}{l}\text { Number of } \\
\text { patients (n) }\end{array}$ & $\begin{array}{l}\text { Percentage } \\
(\%)\end{array}$ \\
\hline Gender & & \\
\hline Female & 62 & 52,5 \\
Male & 56 & 47,5 \\
\hline Age Distribution & & \\
\hline $0-3$ & 76 & 64,4 \\
$4-6$ & 26 & 22 \\
$7-9$ & 11 & 9,3 \\
$>10$ & 5 & 4,2 \\
\hline Signs and Symptoms & & \\
\hline Congenital Heart Disease & 49 & 38,3 \\
Sensorineural Hearing Loss & 37 & 28,9 \\
Cataract Congenital & 23 & 18 \\
Mental Retardation & 12 & 9,4 \\
Microcephaly & 7 & 5,5 \\
\hline
\end{tabular}

Table 2. IgM and IgG of CRS Patients in the Audiology Polyclinic of Dr. Soetomo General Academic Hospital, Surabaya, Indonesia in 2015-2017

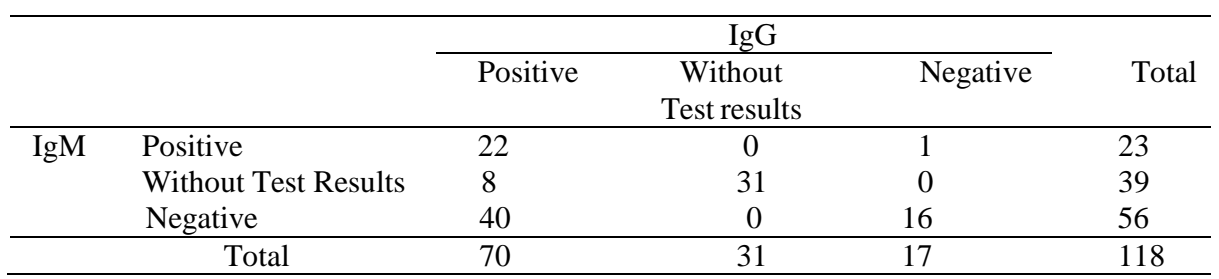

Table 3. The results of Otoacoustic Emissions Testing (OAE) and Automated Auditory Brainstem Response (AABR)

\begin{tabular}{|c|c|c|c|c|c|}
\hline & & \multicolumn{3}{|c|}{ AABR } & \multirow[t]{2}{*}{ Total } \\
\hline & & Pass & $\begin{array}{r}\text { Unilateral } \\
\text { Refer }\end{array}$ & $\begin{array}{c}\text { Bilateral } \\
\text { Refer }\end{array}$ & \\
\hline \multirow{4}{*}{ OAE } & Pass & 29 & 6 & 5 & 40 \\
\hline & Unilateral Refer & 11 & 8 & 8 & 27 \\
\hline & Bilateral Refer & 3 & 3 & 45 & 51 \\
\hline & Total & 43 & 17 & 58 & 118 \\
\hline
\end{tabular}

Note: $\mathrm{P}=$ Pass, $\mathrm{R}=$ Refer

\section{DISCUSSION}

This study showed that the number of male patients is greater than the number of female patients. Besides, the most dominant age group was found in the age group of 0-3 months (64.40\%). Research reports from Sudan revealed that the majority of patients were male $(65.30 \%)$, and most of them were less than 6 months (50\%) (Adam et al., 2014). Research conducted in Japan also found that the majority of patients who experienced CRS were patients with male sex (Singh et al., 2013). Furthermore, the country of Bangladesh also revealed the same thing. Based on 40 suspected CRS cases, $68 \%$ of patients were male and $32 \%$ were female patients. However, this study had not explained the reasons why CRS patients were more dominated by male than female, even though there were many previous studies reported a similar ratio of results (Nazme et al., 2015). Astudy from Canada stated that mothers infected with rubella during pregnancy can cause the baby to be born with congenital rubella syndrome either it is male or female. Therefore, both genders have the same risk of getting infected by rubella syndrome 
from their mother (Canadian Pediatric Society, 2007).

The number of infants diagnosed with rubella who are less than 6 months does not indicate in what age a child begins to be infected by CRS. The infants might have been infected in the perinatal period when the mother is infected with rubella virus. However, the positive rubella infection results are only known when the infants with the risk of rubella infection are born and then examined for IgG and $\operatorname{IgM}$ antibodies. The results of this antibody examination will show results in different times. IgG must be tested from time to time to determine the results, whereas IgM do not need to be tested and the results are shorter (Lindquist et al., 1966). WHO, CDC (Centers of Disease Control and Prevention), and several other international institutions recommend that IgM tests should be performed on infants, because these tests are more specific and the method of tests is also easier than IgG (Hussain et al., 2006). However, IgM tests also have the disadvantage of being able to produce false-positive data on mothers who have high rheumatoid factor (Best et al., 2002).

Furthermore, IgM is more indicative of serological specific markers of rubella virus and can be used as a detection in almost 100\% of infants infected at the age of 0-3 months (Canepa, 2009). The reason for the large number of patients diagnosed with rubella at less than 6 months is most likely due to some of the infants in this study had positive IgM results at the age of 0-3 months, so that at the age of 4-6 months, the infants had positive IgG results.

Investigations in the form of $\mathrm{IgG}$ and $\mathrm{IgM}$ antibodies play an important role in the diagnosis of rubella (Nugroho \& Muyassaroh, 2014). Research in Bangladesh in 2014 showed that the positive IgG results were $60 \%$ of the patients, which were also greater than the positive IgM results which were $28 \%$ of patients. This is similar to the researchers' data which states that the results of positive IgG tests were $59 \%$ of patients and positive IgM tests were $19 \%$ of patients. This also means that there are $59 \%$ of patients indicated by CRS. Based on the study data taken in Ethiopia, the majority of CRS cases in 2015-2017 revealed that there were 74\% of negative IgG and IgM results which could be classified as non-CRS case. Researchers' crosstab data showed that only 16 patients had negative IgG and IgM results. This phenomenon may be caused by other viral agents, such as CMV (cytomegalovirus), Toxoplasma gondii and herpes simplex which cause similar congenital abnormalities to rubella (Wondimeneh et al., 2018).

Infants can be clinically diagnosed with CRS if they have 2 group A symptoms or 1 group A criteria and 1 group B criteria. The criteria of group A consists of congenital cataracts and/or glaucoma, congenital heart disease, decreased hearing, and retinal pigmentation, while the criterial of group B consists of purpura, splenomegaly, jaundice, microcephaly, mental retardation, and radiolucent bone disease (bones appear dark on X-rays) (CDC, 2019).

In this study, the most dominant signs and symptoms that occur were congenital heart disease. There were 49 patients (38.30\%) who had signs and symptoms of congenital heart disease. This was similar to research in Bangladesh which states that the most dominant signs and symptoms occur in Yangon, Myanmar are congenital heart disease by $72 \%$ (Nazme et al., 2015). In Vietnam, based on 292 CRS patients, the most common symptom was congenital heart disease (91.4\%) (Masresha et al., 2018). Similar results have also been reported in several studies in Mexico, Panama and the USA, although surveillance methods are varied (Thant et al., 2006).

There is a strong relationship between perinatal rubella infection and congenital heart cases. If a woman is infected with rubella in less than 5 months and the woman is pregnant with a baby who is less than 12 weeks of pregnancy, the baby is most likely to have congenital rubella syndrome with organ disorders especially in the heart, ears and eyes (Canadian Pediatric Society, 2007). In addition, many cases of congenital heart disease suffered by rubella-infected patients are mostly caused by delays in early detection which will also cause delays in handling both the mother and the baby who are infected by the rubella virus. One study in Spain explained that many health facilities and hospitals did not report, integrate, or suspect rubella syndrome in patients with congenital heart disease. Thus, it can be concluded that not many medical personnel know that congenital heart disease has a strong correlation with rubella infection, and vice versa (Solórzano- Santos et al., 2013).

The second most dominant sign and symptom was hearing loss with 37 patients $(28.90 \%)$ in total. This was different from other studies which stated that the most common abnormality in CRS infants is hearing loss (Of, 2007). Nevertheless, research from Cohen et al. (2014) stated that CRS was strongly associated with hearing loss (Poliana, Queiros and Lima, 2006). It was contrast to the data in Sudan where $24.50 \%$ of infants who were categorized as a clinically-confirmed cases of CRS, with an average age of 4 months, had 13 cases with visual impairment, 4 cases with congenital heart disease, and 7 cases 
with both cases. These results were obtained because the study did not include evaluations of hearing loss due to limitations of participating hospitals and lack of physical tests about hearing (Adam et al., 2014). This difference may also happened due to the correlation of gestational age when the infection of rubella occurred with the organ systems involved, such as vision problems and congenital heart disease that is often affected during the first 8 weeks of pregnancy; whereas mental retardation and hearing loss are more common during 18 weeks of pregnancy. Based on all these studies, the most susceptible time to rubella is in the early trimester of pregnancy (Wondimeneh et al., 2018). The provision of an appropriate and correct vaccine is very effective in preventing the occurrence of CRS in children (CDC, 2019). The data showed that in the span of 10 years from 2000 to 2010, the provision of the right vaccine in developing countries including Indonesia, had reduced the incidence of Measles and rubella infections by $75 \%$ (WHO, 2014). This indicates that the role of vaccines is very important to prevent CRS, so that children are expected to be born normally without any significant disability, and the treatment can be carried out as minimal as possible.

Hearing screening is conducted to separate groups of infants who do not have hearing problems (pass) and groups of infants who have hearing loss (refer). The selection of screening methods which tends to be used in various regions of the world consists of a single method with an OAE or AABR tests and a method that combines the two tests. OAE tests results are pass or refer. However, the results of passing the OAE tests still do not confirm that the patient's hearing is in a normal condition because OAE does not assess the function of the retrochoclea, while the-refer\| test results also have not confirmed any significant hearing loss. Thus, the recommended screening tests use a combination of OAE and AABR because it can reach $100 \%$ of sensitivity and $99.7 \%$ of specificity (Ekorini, 2016).

In the hearing screening channel, all newborn infants will be tested for OAE. After that, AABR tests are conducted to confirm the diagnosis of hearing loss in the infants. The further examination is very necessary, although the OAE screening tests show - passll results. Therefore, AABR tests are recommended to be conducted after 1-3 months. However, AABR tests also have a failure rate of around $4 \%$ which is influenced by the way the technician when performing the tests: the calmness of the baby or when the baby sleeps, the immediate tests after the baby is fed, and the placement of earphones in the baby's ears (Ekorini, 2016). This is in line with the researchers' data regarding the OAE. - pass test results but the unilateral AABR - refer\| was 6 patients and bilateral AABR - refer\| was 5 patients, with a total of 11 patients. Based on its effect, hearing loss is divided into two, such as bilateral and unilateral. According to Cohen et al. (2014), if someone is infected with rubella virus, the CRS is classified as severe and bilateral SNHL (sensorineural hearing loss). This is consistent with the researchers' data which show that bilateral hearing loss with the results of OAE and AABR tests was 45 patients, while unilateral hearing loss on OAE and AABR tests was less that 8 patients. This study indicates that the results of OAE tests with the results of unilateral AABR -referl and bilateral AABR -referl (PR/RP/RR) are as many as 78 patients. These findings are also in line with Ekorini's research in 2016 which explained that there were several factors that can affect the results of OAE screening, namely the middle ear should be in a clean condition, which means that it is free from cerumen, no vernix caseosa, otitis externa, secretions, atresia of the outer ear canal, and the tympanic membrane conditions. If the results of an OAE test are doubtful either it is -passll or -referl, it is better to do a probe tip check and the test should be conducted several times. When the crosstab data with AABR tests were obtained, patients with the -refer\| results from both OAE and AABR (PR/RP/RR) were $64(54.2 \%)$ in total. In addition, from 40 patients with the-passll OAE results, there were 11 patients who had the AABR -referll test results. The data is in accordance with the research by Ekorini (2013) which shows that the results of OAE -referl is not enough to diagnose hearing loss, and therefore, AABR tests are needed to diagnose precisely the decrease or hearing loss in infants. However, there are many patients only do OAE tests without conducting AABR tests since the tests require quite expensive costs.

\section{CONCLUSION}

The age group of patients who suffered from CRS was dominated by the age of 0-3 months. Besides, the number of male patients was also greater than the female patients. The most dominant signs and symptoms were congenital heart disease, followed by hearing loss, visual impairment, mental retardation and microcephaly respectively. Furthermore, serological tests results for the CRS were dominated by negative $\operatorname{IgM}$ and positive $\operatorname{IgG}$, while the results of the auditory hearing screening test 
were dominated by bilateral OAE and bilateral AABR - referll. Further evaluation is needed regarding vaccines that have been given to infants since it will be very useful for researchers to find out the origin of rubella infection based on the maternal or exposure from the environment. In addition, every health facility should be able to maintain the completeness of medical record data which is very necessary for further retrospective research.

\section{REFERENCES}

Adam, O., Ali, A.K.M., Hübschen, Muller, J.M., Claude P., 2014. Identification of congenital rubella syndrome in Sudan. BMC Infectious Disease, 14(2): 1-5.

Best, J.M. O'shea, S., Tipples, G., Davies, N., Al- Khusaiby, S.M., Hesketh, K.A., Louise, M., Jin, Li., Enders, G., 2002. Interpretation of rubella serology in pregnancy-pitfalls and problems. BMJ Journal, 325(7356): 147.

Canadian Paediatric Society, 2007. Rubella (German measles) in pregnancy. Downloaded 20 November 2019 from https://www.ncbi.nlm.nih.gov/pmc/articl.

Canepa, P., 2009. Role of congenital rubella reference laboratory: 21-months- surveillance in Liguria, Italy. Journal of Preventive Medicine and Hygiene, 50(4): 221-6.

Cherow, E. 2000. Year 2000 position statement: Principles and guidelines for early hearing detection and intervention programs. American Journal of Audiology, 9(1): 9-29.

Ekorini, H.M., 2013. Pemeriksaan Otoacoustic Emission dan Brainstem Evoked Response Audiometry pada bayi dan anak. PERHATI-KL, 1(1): 1-16.

Ekorini, H.M., 2016. Skrining pendengaran bayi baru lahir dalam praktik klinis, Ilmu Kesehatan Bedah THT-KL RSUD Dr. Soetomo, 1(1)

Hardiana, A.T., Raksanagara, A.S., Judistiani, Rd., Tina, D., Bachtiar, W.D., Novilia S., 2015. Distribution and genotypic analysis of rubella virus in West Java on 2011-2013. Indonesian Journal of Clinical Pharmacy, 4(1): 1-7.

Hussain, N., Jaffery, G., Hasnain, S., Anwar, M.S., 2006. Seroprevalence of rubella IgG and IgM antibodies in infants suspected of having rubella infection. Biomedica, 22(1): 25-30.

Ministry of Health, Republic of Indonesia, 2019. Imunisasi MR penting diberikan untuk anak [MR immunization is important for children]. Downloaded : 20 November 2019 from http://www.depkes. go.id/article/view/17081400003/imunisasi-mr-penting-diberikan-untuk melindungi-anak.html

Lindquist, J.M., Plotkin, S.A., Shaw, L., Gilden, R.V., Williams, M.L., 1966. Congenital rubella syndrome as a systemic infection. Studies of affected infants born in Philadelphia, U.S.A., British Medical Journal, 2(5475): 1401-6.

Masresha, B., Shibeshi, M., Kaiser, R., Luce, R., Katsande, R. Mihigo, R., 2018. Congenital rubella syndrome in the African Region. Data from Sentinel Surveillance. Journal of Immunological Sciences, 2(1): $145-149$.

Nazme, N.I., Hussain, M., Hoque, M.M., Dey, A.C., Das, A.C., 2015. Study of cardiovascular malformation in congenital rubella syndrome in two tertiary level hospitals of Bangladesh. Bangladesh Journal of Child Health, 38(3): 137-41.

Nugroho, D.A., Muyassaroh., 2014. Tuli kongenital diduga akibat infeksi rubela dan sitomegalovirus. Medica Hospital, 2(2): 130-6.

Poliana, L., Queiros, F., Lima, I., 2006. Etiology of Hearing Impairment. Brazilian Journal of Otorhinolaryngology. 72(1): 33-36.

Sadighi, J., Eftekhar, H., Mohammad, K., 2005. Congenital rubella syndrome in Iran. BMC Infectious Diseases, 5(44): 1-7.

Singh, S., Bingwor, F., Tayler-Smith, K., Manzi, M., Marks, G. B., 2013. Congenital rubella syndrome in Fiji, 1995-2010. Journal of Tropical Medicine, 1(1): 1-6.

Solórzano-Santos, F., Bárcenas-López, S.J., Huerta-García, G.C., Miranda-Novales, M.G., Alvarez Muñoz, M.T., Vázquez- Rosales, J.G., 2013. Perinatal infection by rubella virus in breast-fed babies with congenital heart disease. Revista médica del Instituto Mexicano del Seguro Social, 51(2): 15863.

Thant, K.Z., Oo, W.M. Myint, T.T., Shwe, T.N., Han, A.M., Aye, K.M., Aye, K.T., Moe, K.T.S., Robertson, S.E., 2006. Active surveillance for congenital rubella syndrome in Yangon, Myanmar. Bulletin of the World Health Organization, 84(1): 12-20. 
World Health Organization, 2014. Strategic plan for measles elimination and rubella and congenital rubella syndrome control in the South-East Asia Region. 1st ed. New Delhi: WHO Library Cataloguing.

Wondimeneh, Y., Tiruneh, M., Ferede, G., Denekew, K., Admassu, F., Tessema, B., 2018. Hospital based surveillance of congenital rubella syndrome cases in the pre-vaccine era in Amhara Regional State, Ethiopia: A base line information for the country. PloS one, 13(11): 0207095. 